\title{
ANALISIS FAKTOR PELAYANAN, SARANA PRASARANA, KEUNIKAN OBJEK, DAN KEAMANAN YANG MEMPENGARUHI KETERTARIKAN WISATAWAN PADA PANTAI BARON GUNUNGKIDUL
}

\author{
Mentari Herdianingsih \\ mentariherdia@gmail.com \\ Universitas Ahmad Dahlan \\ Sukardi \\ Sukardu_feuad@yahoo.com \\ Universitas Ahmad Dahlan
}

\begin{abstract}
ABSTRAK
This study aims to determine whether: service factors affect tourist attraction, infrastructure facilities influence tourist attraction, object uniqueness factors affect tourist attraction and security factors affect tourist attraction. And know the magnitude of the influence of factors of service, infrastructure, uniqueness of objects, and safety simultaneously on the attraction of tourists to Baron Gunungkidul Beach. The population in this study is the visitor / tourist attraction of Baron Beach. Samples taken as many as 100 respondents using the Accidental Sampling technique (sampling choose who happened to be / found) and using the Purposive Side technique that is deliberate sampling (researchers determine their own samples taken because there are certain considerations). Based on the results of research that has been tested: service has a positive and significant effect on tourist attraction, Infrastructure has a positive and significant effect on tourist attraction, The uniqueness of the object has a positive and significant effect on tourist interest, Security has a positive and significant effect on tourist interest and simultaneous service variables, infrastructure, uniqueness of objects and security have a significant effect on the attraction of tourism in the Baron beach tourism object. While the magnitude of the influence of the four independent variables on the dependent variable is $54.7 \%$, and the remaining $45.3 \%$ tourist interest is influenced by other variables.
\end{abstract}

Keyword: services, infrastructure, uniqueness of objects, security.

\section{PENDAHULUAN}

Indonesia merupakan sebuah negara yang memiliki berbagai ragam kebudayaan dan sumber daya alam yang merupakan modal utama untuk meningkatkan taraf hidup bangsa melalui pendayagunaan kekayaan yang dimilikinya. Salah satu kekayaan yang dimiliki Indonesia adalah ditemukanya berbagai macam tempat objek wisata dengan daya tarik dan ciri khas tersendiri, sehingga dapat menarik perhatian para wisatawan baik domestik maupun mancanegara untuk berkunjung ke Negara Indonesia, khususnya di Propinsi Daerah Istimewa Yogyakarta, Kabupaten Gunungkidul yang memiliki banyak objek wisata bernilai religius, historis dan ekonomi yang tinggi. Dari 4 Kabupaten di Yogyakarta, Gunungkidul mungkin merupakan salah satu yang paling tersohor.Karakteristik utama pariwisata di Gunungkidul adalah mengandalkan bentang alam yang indah, budaya tradisional yang terjaga, garis pantai yang sangat luas dan mempesona. Diungkapkan Bupati Gunungkidul Hj Badingah ketika 
menerima audensi pengurus Persatuan Wisatawan Indonesia (PWI) Cabang Yogyakarta, di kantor Wonosari. Beliau mengungkapkan bahwa "Wilayah Kabupaten Gunungkidul memiliki potensi objek wisata alam yang beragam yaitu meliputi kawasan pantai, gua bawah tanah dan pegunungan karst. Gunungkidul juga memiliki objek wisata alam unggulan berupa 46 kawasan pantai yang membentang dari timur hingga barat wilayah Kabupaten itu sepanjang 70 kilometer. Wilayah ini juga memiliki 400 gua dibawah tanah yang di dalamnya mengalir air sungai menuju pantai selatan, dan sebagian menjadi objek wisata alam yang diunggulkan. Diantaranya objek wisata susur Gua Pindul, Gua Kali Suci dan sebagainya ".1Dengan banyaknya obyek wisata di Kabupaten Gunungkidul, butuh waktu yang sangat lama untuk menjelajah semua pesona yang ada disana. Dari berbagai wisata yang ada di Kabupaten Gunungkidul, penulis memilih objek wisata pantai. Sebab berada di selatan Yogyakarta, Kabupaten ini sangat kaya akan panorama pantainya. Objek wisata pantai disana juga memiliki keunikan tersendiri. Selain itu, kawasannya masih alami seperti Pantai Baron yang merupakan pintu gerbang masuk kawasan objek wisata pantai di Kabupaten ini. Asal mula nama Pantai Baron berasal dari nama seorang bangsawan asal Belanda yang bernama Baron Skeber. Bangsawan tersebut pernah mendaratkan kapalnya di pantai selatan tepatnya di pantai yang saat ini terkenal dengan sebutan Pantai Baron. Pantai ini terletak kurang lebih 40 km dari Yogyakarta ini menyimpan pesona yang sangat indah. Kontur lembah dan sungai air tawarnya menjadi magnet tersendiri bagi wisatawan yang datang. Begitu juga dengan ditambahnya mercusuar yang bertempat di Pantai Baron Gunungkidul yang membuatnya berbeda dengan pantaipantai lainnya. Akses jalan menuju Pantai Baron dapat dibilangaman sebab infrastruktur masuk kewilayah ini sangat baik dan cukup mudah dijangkau meski dengan jalanan yang berkelok kelok, menjadikannya sebagai ciri khas pantai-pantai di Gunungkidul. Akan tetapi jangan khawatir, selama perjalanan Anda akan disuguhi beraneka pemandangan alam permai yang membuat mata lebih segar, seperti bukit-bukit hijau, sawah dan lanskap yang eksotis. Pantai Baron menebar pesona lewat kontur lembah di kanan kiri bibir pantai. Di sebelah kanan, pengunjung dapat melihat sungai air tawar yang bermuara langsung menuju laut. Jajaran perahu-perahu nelayan juga akan dijumpai di Pantai Baron yang menjadi pemandangan yang menarik untuk para wisatawan.

Meskipun Pantai ini memangdijadikan dermaga untuk berangkat dan pulang ketika mencari nafkah di Samudera Hindia. Di kawasan ini juga dilengkapi dengan Tempat Pelelangan Ikan (TPI) sebagai tempat jual beli hasil tangkapan laut. Begitu juga dengan pelayanan yang baik dan keramah tamahan dari setiap petugas, telekomunikasi, adanya money charger untuk para wisatawan asing. Keamanan disini juga didukung oleh adanya tim sar. Berbagai macam fasilitas sarana prasarana sebagai pendukung di Pantai Baron juga dapat dimanfaatkan dengan baik, seperti lahan parkir yang luas, restoran/warung makan dengan sajian seafood yang memang lebih banyak dibanding dengan pantai pantai lain, toko cinderamata, penginapan/hotel dengan harga terjangkau, camping ground di sekitar pantai, dan tempat pemancingan ikan. Jika di lihat dari nilai religiusnya dipantai ini setiap tahunnya mengadakan upacara sedekah laut yaitu upacara yang masih sering dilakukan oleh masyarakat Gunungkidul. Pantai Baron adalah salah satu tempat untuk menyelenggarakan setiap tanggal satu Suro dalam penanggalan Jawa. Upacara sedekah laut dilakukan sebagai ungkapan rasa syukur penduduk setempat atas 
melimpahnya tangkapan ikan di Pantai Baron.

Namun demikian, banyaknya tempat wisata pantai di Gunungkidul membuat Pantai Baron mendapatkan banyak pesaing pantai lain yang ada disekitarnya. Berbagai faktor yang dapat mempengaruhi wisatawan pasti akan dilakukan oleh setiap pengelola supaya pantai tersebut semakin banyak dikenal orang dan membuat pengunjung tertarik untuk berkunjung ke pantai tersebut. Dalam menyikapi hal-hal tersebut, pengelola pantai baron terus melakukan perbaikan dan memaksimalkan potensi yang ada pada Pantai Baron tersebut. Dapat dilihat saat ini jumlah pengunjung Pantai Baron dari tahun ke tahun memang cenderung mengalami kenaikan, apalagi ketik weekend dan hari libur sekolah. Akan tetapi peningkatan jumlah kunjungan dari tahun ke tahun bukan merupakan suatu hasil kerja yang optimal. Pada dasarnya pengelolaan Pantai Baron mempunyai potensi yang baik. Permasalahannya adalah bagaimana kawasan Pantai Baron dapat dipertahankan keunikannya maupun ekosistemnya, bahkan diharapkan dalam menunjang pendapatan daerah untuk lebih besar lagi kontribusinya.

\section{Rumusan Masalah}

1. Apakah terdapat pengaruh variabel Pelayanan terhadap ketertarikan wisatawan pada Pantai Baron Gunungkidul?

2. Apakah terdapat pengaruh variabel Sarana Prasarana terhadap ketertarikan wisatawan pada Pantai Baron Gunungkidul?

3. Apakah terdapat pengaruh variabel Keunikan Objek terhadap ketertarikan wisatawan pada Pantai Baron Gunungkidul?

4. Apakah terdapat pengaruh variabel Keamanan terhadap ketertarikan wisatawan pada Pantai Baron Gunungkidul?
5. Apakah terdapat pengaruh secara simultan variabel pelayanan, sarana prasarana, keunikan objek, dan keamanan terhadap ketertarikan wisatawan pada Pantai Baron Gunungkidul?

\section{REVIEW LITERATUR DAN HIPOTESIS}

\section{Landasan Teori \\ Pengertian Pemasaran}

Pemasaran merupakan faktor vital sebagai strategi perusahaan dalam menjalankan usahanya, yang terutama berhubungan dengan konsumen. Kata pemasaran sendiri berasal dari kata pasar, atau bisa juga diartikan dengan mekanisme yang mempertemukan permintaan dan penawaran. Menurut (Kotler, 2006) "Pemasaran adalah proses sosial yang dengan proses itu individu dan kelompok mendapatkan apa yang mereka butuhkan dan inginkan dengan menciptakan, menawarkan, dan secara bebas mempertukarkan produk dan jasa yang bernilai dengan pihak lain.

\section{Manajemen Pemasaran}

Menurut (Kotler dan Armstrong, 2004), Manajemen pemasaran adalah analisis, perencanaan, penerapan, dan pengendalian program-program yang dirancang untuk menciptakan,membangun, dan mempertahankan pertukaran yang saling menguntungkan dengan pembeli sasaran dalam rangka mencapai tujuan organisasi. Proses itu melibatkan lebih dari sekedar mendapat cukup pelanggan bagi output perusahaan saat ini. Lebih dari sekedar merancang strategi untuk menarik konsumen baru dan menciptakan transaksi dengan mereka, perusahaan sekarang ini berfokus pada mempertahankan pelanggan saat ini dan membangun hubungan jangka panjang melalui penawaran nilai dan kepuasan yang unggul bagi pelanggan. Perusahaan yang sukses saat ini besar atau kecil, pencari laba atau nirlaba, domestik atau global benar-benar fokus pada 
konsumennya dan berkomitmen pada pemasaran. Pemasaran berupaya menarik konsumen dengan menjanjikan nilai yang unggul dan tetap mempertahankan konsumen lama dengan memberikan kepuasan. Agar sukses, perusahaan harus benar-benar berfokus pada pasar. Pemasaran adalah proses sosial dan manajerial dimana individu dan kelompok memperoleh apa yang mereka ingin dan butuhka melalui penciptaan dan pertukaran barang dan nilai dengan pihak lain.

\section{Pengertian Pariwisata}

Pariwisata menurut UU Nomor 9 Tahun 1990 secara jelas dan tegas menyatakan bahwa wisata adalah kegiatan perjalanan atau sebagian dari kegiatan tersebut yang dilakukan secara sukarela dan bersifat sementara, untuk menikmati objek dan daya tarik wisata. Unsur yang terpenting dari kegiatan kepariwisataan adalah tidak bertujuan mencari nafkah, tetapi apabila di sela-sela kegiatan mencari nafkah itu juga secara khusus dianggap kegiatan.

\section{Pelayanan Kepariwisataan}

Pengertian pelayanan menurut (Kamus Besar Indonesia, 2001) adalah perihal atau cara melayani, usaha melayani kebutuhan orang lain dengan memperoleh imbalan (uang); jasa dan kemudahan yang diberikan sehubungan dengan jual beli barang atau jasa. Menurut (Kotler, 2002) definisi pelayanan adalah setiap tindakan atau kegiatan yang dapat ditawarkan oleh sesuatu pihak kepada pihak lain, yang pada dasarnya tidak berwujud dan tidak mengakibatkan kepemilikan apapun. Produksinya dapat dikaitkan atau tidak dikaitkan pada produk fisik. Pelayanan merupakan perilaku produsen dalam rangka memenuhi kebutuhan dan keinginan konsumen demi tercapainya kepuasan pada konsumen itu sendiri. Kotler juga mengatakan bahwa perilaku tersebut dapat terjadi pada saat, sebelum dan sesudah terjadinya transaksi.

\section{Sarana Prasarana Pariwisata}

Menurut (Inskeep, 1991), Sarana pariwisata disebut sebagai ujung tombak usaha kepariwisataan dapat diartikan sebagai usaha yang secara langsung maupun tidak langsung memberikan pelayanan kepada wisatawan pada suatu daerah tujuan wisata dimana keberadaannya sangat tergantung kepada adanya kegiatan perjalanan wisata. Sedangkan prasarana wisata adalah sumber daya alam dan sumber daya buatan manusia yang mutlak dibutuhkan oleh wisatawan dalam perjalanan didaerah tujuan wisata prasarana dasar yang melayani penduduk lokal seringkali juga melayani kegiatan pariwisata, seperti jalan, sumber listrik dan energi sumber air dan sistem pengairan fasilitas kesehatan, dan sebagainya. Dalam melaksanakan pembangunan prasarana wisata perlu disesuaikan dan mempertimbangkan kondisi dalam lokasi yang akan meningkatkan.

\section{Keunikan Objek Pantai Baron}

Pantai Baron adalah salah satu objek wisata berupa pantai yang terletak di Desa Kemadang, Kecamatan Tanjungsari, Kabupaten Gunungkidul. Lokasi Pantai Baron dapat ditempuh $40 \mathrm{~km}$ dari pusat kota Yogyakarta. Pantai ini sebenarnya berupa teluk yang diapit oleh dua buah bukit di sisi kanan dan kiri. Pasir berwarna cokelat menghampar disepanjang pantai. Jajaran perahu-perahu nelayan juga akan dijumpai di Pantai Baron yang menjadi pemandangan yang menarik untuk para wisatawan.

\section{Keamanan Pariwisata}

Menurut (Kövàri dan Zimànyi, 2011), Kenyamanan dan keamanan menjadi kondisi yang penting dalam industri pariwisata. Aspek tersebut pada dua dekade terakhir telah menjadi isu yang semakin besar dan mempunyai dampak yang sangat besar terhadap keberlangsungan aktvitas perjalanan dan kepariwisataan. Ancaman kenyamanan dan 
keamanan wisatawan dapat dipenggaruhi dan disebabkan oleh beragam faktor, sepertiaksi teroros, konflik lokal, bencana alam, perilaku sosial masyarakat dan penyakit menular sehingga hal tersebut dapat menyebabkan menurunya rasa aman bagi wisatawan. Kenyamanan dan keamanan bagi wisatawan merupakan salah satu faktor yang menentukan kepuasan untuk melakukan suatu perjalanan ke suatu destinasi pariwisata.

\section{Wisatawan}

Pengertian wisatawan yang tertuang dalam Instruksi Presiden Nomor 9 Tahun 1969 memberikan definisi wisatawan (tourist) adalah orang yang berpergian dari tempat tinggalnya untuk berkunjung ke tempat lain dengan menikmati perjalanan dan kunjungan itu.

\section{Ketertarikan Wisatawan}

(Fandeli, 1995) menyatakan bahwa Minat wisatawan merupakan ketertarikan seseorang dari orang-orang yang ingin melakukan suatu perjalanan untuk mengetahui suatu perjalanan untuk mengetahui sesuatu yang unik di suatu daerah. Biasanya orang-orang yang melakukan kegiatan perjalanan tourist. Minat seorang wisatawan adalah adanya Minat Khusus dari dan Wisata Alam. Namun dunia pariwisata menidentifikasi bahwa adanya minat khusus wisatawan dikarenakan adanya suatu keunikan. Dari pengertian diatas dapat disimpulkan bahwa ketertarikan wisatawan bisa juga dikatakan dengan minat wisatawan.

\section{Perilaku Wisatawan}

Para ahli mendefinisikan perilaku wisatawan, menurut (Morrisan, 2007) perilaku wisatawan adalah proses dan kegiatan yang terlibat ketika orang mencari, memilih, menggunakan, mengevaluasi, dan membuang produk dan jasa untuk memuaskan kebutuhan dan keinginan mereka. Menurut (Buchari, 2008) Perilaku wisatawan adalah proses pengambilan keputusan dan kegiatan fisik individu-individu yang semuanya ini melibatkan individu dalam menilai, mendapatkan, menggunakan, atau mengabaikan barang-barang dan jasa-jasa.

\section{Penelitian Terdahulu}

Penulis mengadakan penelitian ini berdasarkan penelitihan terdahulu yang diambil oleh beberapa peneliti sebelumnya yang sesuai dengan penelitian yang diambil. Penelitian-penelitian yang sesuai dengan penelitian ini diantaranya adalah : 1. Menurut Yoeti (1997)

Fasilitas adalah segala sesuatu baik bendamaupun jasa yang menyertai pelayanan yang diberikan oleh perusahaanbaik perusahaan jasa, dagang maupun perusahaan industri. Fasilitas dapatjuga diartikan sebagai sarana dan prasarana yang tersedia di lingkunganmaupun di dalam kantor perusahaan, dimaksudkan untuk memberikanpelayanan maksimal agar konsumen atau pelanggan merasakan nyamandan puas. Fasilitas merupakan faktor penunjang utama dalam kegiatansuatu produk.

2. Penelitian terdahulu yang dilakukan (Syahadat, 2005) dengan judul: Faktor - Faktor Yang Mempengaruhi Kunjungan Wisatawan Di Taman Nasional Gede Pangrango (TNGP), penelitian ini bertujuan untuk mengetahui besarnya pengaruh faktorfaktor tersebut secara bersama- sama (simultan) terhadap jumlah pengunjung, Analisis data dilakukan dengan menggunakan metode analisis regresi linier berganda. Hasil penelitian menunjukkan bahwa faktor pelayanan, faktor sarana prasarana, faktor obyek dan daya tarik wisata alam, dan faktor keamanan secara bersama-sama (simultan) mempunyai pengaruh terhadap jumlah pengunjung akan tetapi tidak secara nyata (tidak signifikan) di Taman Nasional Gede Pangrango. Akan tetapi secara parsial, dari keempat faktor tersebut faktor keamanan yang mempunyai pengaruh yang signifikan 
(nyata) dan dominan terhadap jumlah pengunjung di Taman Nasional Gede Pangrango.

3. Penelitian Bursan (2006) menyatakan bahwa kepuasan terhadap objek wisata yang dapat dipengaruhi oleh keindahan alamlokasi, kebersihan lokasi, kenyamanan lokasi, keamanan lokasi, keunikan fisik lokasi, keunikan budaya, keramah tamahan masyarakat, ketrampilan pemandu wisata, tarif jasa pemandu. Kepuasan Wahana Wisata dapat diprediksi oleh variabel fasilitas alan raya, kenyamanan jalan raya, keamanan jalan raya, fasilitas bandara/ pelabuhan/ terminal, kecepatan layanan kenyamanan, keramahan masyarakat sekitar, sarana komunikasi, ketetapan waktu.

\section{Hipotesis}

H1: Terdapat pengaruh faktor Pelayanan terhadap ketertarikan wisatawan pada Pantai Baron Gunungkidul

H2: Terdapat pengaruh faktor Sarana Prasarana terhadap ketertarikan wisatawan pada Pantai Baron Gunungkidul.

H3: Terdapat pengaruh faktor Keunikan Objek terhadap ketertarikan wisatawan pada Pantai Baron Gunungkidul.

H4: Terdapat pengaruh faktor Keamanan terhadap ketertarikan wisatawan pada Pantai Baron Gunungkidul

H5: Terdapat pengaruh faktor pelayanan, sarana prasarana, keunikan objek dan keamanan secara simultan terhadap ketertarikan wisatawan pada Pantai Baron Gunungkidul.

\section{METODE PENELITIAN}

\section{Populasi dan Sampel}

Populasi berasal dari bahasa inggris, population yang berarti jumlah penduduk. Populasi dalam penelitian merupakan keseluruhan dari obyek yang dapat berupa manusia, hewan, tumbuhan, gejala, niali, peristiwa, dan sebagainya, sehingga obyek-obyek ini dapat menjadikan sember data penelitian (Bungin, 2009). Dalam penelitian tentang pengaruh ketertarikan wisatawan pada Pantai Baron ini, yang akan menjadi populasi merupakan pengunjung obyek wisata Pantai Baron.

Sampel menurut (Sugiyono, 2004) adalah bagian dari jumlah dan karakteristik yang dimiliki oleh populasi tersebut. Sampel merupakan bagian yangberguna bagi tujuan penelitian populasi dan aspekaspeknya.

\section{Definisi Operasional}

1. Variabel Independen

Devinisi Operasional Variabel dalam penelitian ini terdiri dari variabel independen terhadap ketertarikan wisatawan di objek wisata Pantai Gunungkidul. Variabel independen ini terdiri dari 4 variabel, yaitu ; 1. Faktor pelayanan (X1), pernyataan wisatawan tentang sikap dan prilaku dalam memberikan jasa pelayanan, pemanduan, dan informasi kepada wisatawan, dengan indikator (a) keramahan, (b) kecepatan, (c) keakuratan / kesesuaian informasi yang diberikan, dan (d) kualitas pemandu wisata dalam menerangkan obyek tersebut. Pada Pantai Baron Gunungkidul jenis pelayanan yang diberikan, yaitu : Pelayanan proses perijinan atau penjualan tiket masuk kawasan, Pelayanan informasi, Pelayanan kebersihan dan Pelayanan pemanduan.

2. Faktor Sarana Prasarana (X2), yaitu pernyataan wisatawan tentang fasilitas yang mendukung kelancaran aktivitas wisatawan selama berada di daerah/lokasi obyek wisata, dengan indikator (a) ketersediaan dan (b) kelayakan.

3. Keunikan Objek (X3), yaitu potensi yang ada di objek Pantai 
Baron yang berbasis pengembangan pariwisata air yang bertumpu pada potensi utama sumber daya alam. Demikian halnya dengan pengembangan pariwisata air di Pantai BaronGunungkidul yang memiliki potensi yang cukup unik, antara lain berupa keanekaragaman hayati, dan keindahan panorama alam.

4. Faktor keamanan (X4), tingkat gangguan / kerawanan keamanan di suatu obyek wisata alam akan mempengaruhi ketenangan dan kenyamanan wisatawan selama berada di obyek wisata alam tersebut, disamping itu faktor keamanan tersebut juga akan mempengaruhi wisatawan dalam mengambil keputusan layak atau tidak obyek wisata alam tersebut untuk dikunjungi.

2. Variabel Dependen

Ketertariakan wisatawan (Y), ketertarikan dari seseorang yang ingin mengunjungi Pantai Baron untuk mengetahui sesuatu yang unik pada tempat wisata tersebut.

\section{Uji Instrumen}

1. Uji Validitas

Validitas suatu alat ukur adalah apakah suatu alat ukur dapat mengukur apa yang sebenarnya ingin diukur. Uji validitas perlu dilakukan untuk mengetahui sejauh mana suatu alat ukur yang digunakan dalam penelitian dapat mengukur apa yang sebenarnya ingin peneliti ukur atau dapat digunakan untuk menguji instrumen penelitian agar instrumen tersebut dapat memberikan hasil sesuai dengan tujuan. (Cooper dan Schindler, 2001). Pengujian validitas yang dilakukan adalah construct validity dengan metode confirmatory factor analysis yang dilakukan dengan bantuan program SPSS. Analisis faktor digunakan dalam analisis penelitian ini karena merupakan salah satu metode statistik multivariate yang tujuan utamanya untuk meringkas atau mengurangi data atau variabel yang akan diperlukan untuk dianalisis. Analisis faktor memecahkan masalah yang menyangkut hubungan timbal balik antara sejumlah indikator dan kemudian menjelaskan keterkaitan antara indikator ke dalam dimensi dimensi yang mendasari hubungan tersebut. Dan karena item-item pertanyaan dalam kuesioner diadopsi dari penelitian sebelumnya dengan dimodifikasi maka analisis faktor yang dilakukan bersifat confirmatory, yaitu saat pengolahan pada tahap exsraxtion dipilih number of factor adalah sesuai dengan variabel yang diuji dalam model penelitian. Kriteria signifikasi terhadap item-item pertanyaan dalam penelitian ini didasarkan pada signifikasi (practical significance) (Hair et al., 1998).

\section{Uji Reliabilitas}

Uji reliabilitas untuk menguji ketepatan instrumen pengukur dengan konsistensi diantara bitir-butir pernyataan dalam suatu instrumen. Reliabilitas berkaitan dengan ketepatan prosedur pengukuran dan konsistensi. Suatu alat ukur yang dinilai reliabel jika pengukur tersebut menunjukan hasil-hasil yang konsisten dari waktu ke waktu. Peneliti menguji instrumen peneliti dengan sampel sejumlah 30 responden. Koefisien reliabilitas ditunjukan oleh koefisien Cronbach Alpa berarti semakin tinggi reliabilitas alat ukur yang digunakan. Untuk mengukur reliabilitas dalam penelitian ini adalah dengan membandingkan Cronbach Coefficient Alpha (r Alpha) pada hasil olahan SPSS Release 13.0 dengan Rule of Thumb / kesepakatan umum dari koefisien alfa yaitu lebih besar dari 0,6 untuk penelitian eksploratori. 


\section{Teknik Analisis Data}

1. Analisis Regresi Berganda

Analisis regresi berganda dalam penelitian ini bertujuan untuk mengetahui besarnya pengaruh variabel dependen (variabel pelayanan, sarana prasarana, keunikan objek dan keamanan) terhadap variabel dependen jumlah kunjungan wisatawan. Adapun bentuk umum persamaan regresi berganda yang digunakan dalam penelitian ini adalah sebagai berikut : $\mathrm{Y}=\mathrm{a}+\mathrm{b} 1 \mathrm{X} 1+\mathrm{b} 2 \mathrm{X} 2+\mathrm{b} 3 \mathrm{X} 3+\mathrm{b} 4 \mathrm{X} 4+$ $\mathrm{e}$

dimana:

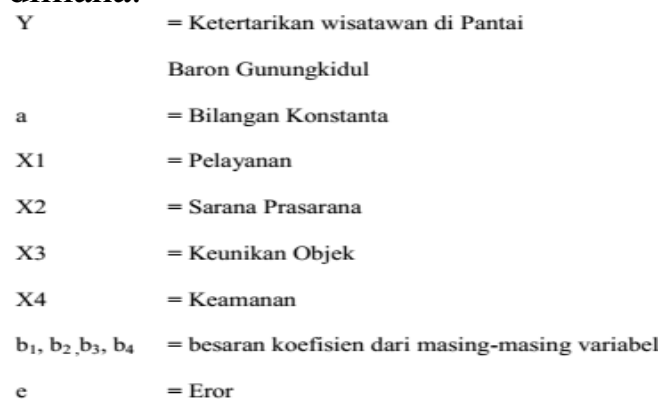

\section{Uji Hipotesis}

\section{Uji Parsial (Uji T)}

Uji menentukan koefisien spesifik yang mana yang tidak sama dengan nol, uji tambahan diperlukan yaitu dengan menggunakanujit.

a. Dasar pengambilan keputusan (Ghozali, 2005) adalah dengan menggunakan angka probabilitas signifikan, yaitu:

i. Apabila angka probabilitas signifikan $>0.05$, maka Ho diterima dan $\mathrm{Ha}$ ditolak.

ii. Apabila angka probabilitas signifikan $<0.05$, maka Ho ditolak dan $\mathrm{Ha}$ diterima.

\section{Uji Simultan (Uji F)}

Uji $f$ digunakan untuk mengetahui tingkat signifikan pengaruh variabelvariabel independen secara bersama (simultan) terhadap variabel dependen (Ghozali,2005).

a. Hipotesis yang digunakan sebagai berikut: i. Apabila probabilitas signifikan > 0.05, Ho diterima Ha ditolak. ii. Apabila probabilitas signifikan < 0.05, Ho ditolak $\mathrm{Ha}$ diterima

\section{Uji Koefisien Determinasi}

Nilai koefisien determinasi merupakan suatu ukuran yang menunjukan besar sumbangan dari variabel penjelas terhadap variabel respon. Dengan kata lain, koefisien determinasi menunjukan ragam (variasi)naik turunya $\mathrm{Y}$ yang diterangkan oleh linier $\mathrm{X}$ (berapa bagian keragaman dalam variabel $\mathrm{X}$ ). (Siagian dan Sugiarto, 2006).

\section{HASIL PENELITIAN DAN PEMBAHASAN}

\section{Hasil Analisis Responden}

Tabel 4.1

Jenis Kelamin Responden

\begin{tabular}{|c|c|c|}
\hline \multicolumn{3}{|c|}{ Jenis Kelamin Responden } \\
\hline Jenis Kelamin & Jumlah & Persentase \\
\hline Laki - laki & 51 & $51 \%$ \\
\hline Perempuan & 49 & $49 \%$ \\
\hline Jumlah & 100 & $100 \%$ \\
\hline
\end{tabular}

Sumber:Data primer yang diolah, 2015

Berdasarkan Tabel 4.1 dapat diketahui bahwa $51 \%$ responden berjenis kelamin laki-laki dan $49 \%$ responden berjenis kelamin perempuan. Hal ini menunjukkan wisatawan yang datang berkunjung di Obyek wisata Baron hampir sama antara wisatawan pria maupun wanita.

\begin{tabular}{|c|c|c|}
\hline \multicolumn{3}{|c|}{$\begin{array}{c}\text { Tabel } 4.2 \\
\text { Usia Responden }\end{array}$} \\
\hline Usia & Jumlah & Persentase \\
\hline $17-25$ tahun & 63 & $63 \%$ \\
\hline $26-35$ tahun & 13 & $13 \%$ \\
\hline $36-45$ tahun & 14 & $14 \%$ \\
\hline$>45$ tahun & 10 & $10 \%$ \\
\hline Total & 100 & $100 \%$ \\
\hline
\end{tabular}

Dari data diatas menunjukkan bahwa turis Pantai Baron mayoritas berusia antara 17 - 25 tahun yaitu sebesar 63\% (63 orang). Sedangkan distribusi usia yang lain yaitu usia antara $26-35$ tahun sebesar $13 \%$ 
(13 orang), antara $36-45$ tahun sebesar $14 \%$ (14 orang) dan terakhir berusia lebih dari 45 tahun sebesar $10 \%$ atau 10 orang. Kenyataan menunjukkan bahwa mayoritas turis adalah berusia muda atau produktif. Salah satu hal yang paling menarik dari obyek wisata Pantai Baron adalahwisata alamnya yang berupa pantai yang disukai oleh kalangan muda.

Tabel 4.3

Profesi Responden

\begin{tabular}{|c|c|c|}
\hline Profesi & Jumlah & Persentase \\
\hline Pelajar & 9 & $9 \%$ \\
\hline Mahasiswa & 41 & $41 \%$ \\
\hline Pegawai & 43 & $43 \%$ \\
\hline Lainnya & 7 & $7 \%$ \\
\hline Total & 100 & $100 \%$ \\
\hline ber: Data primer yang diolah, 2015
\end{tabular}

Dari tabel 4.3 diatas menunjukan bahwa pekerjaan responden mayoritas adalah pegawai yaitu sebesar 43\% (43 orang). Sedangkan distribusi tingkat pekerjaan yang lain yaitu pelajar sebesar $9 \%$ (9 orang), mahasiswa sebesar $41 \%$ (41 orang), dan terakhir adalah turis yang mempunyai pekerjaan lainnya sebesar 7orang atau 7\%. Hal ini disebabkan karena pegawai telah memiliki pendapatan dan pekerjaan tetap, sehingga membutuhkan tempattempat wisata untuk berlibur, dan destinasi wisata yang paling dikenal di Gunung Kidul adalah Pantai Baron.

Tabel 4.4

Frekuensi Kunjungan

\begin{tabular}{|c|c|c|}
\hline $\begin{array}{c}\text { Frekuensi } \\
\text { kunjungan }\end{array}$ & Jumlah & Persentase \\
\hline $1 \mathrm{kali}$ & 0 & $0 \%$ \\
\hline $2 \mathrm{kali}$ & 26 & $26 \%$ \\
\hline$>2 \mathrm{kali}$ & 74 & $74 \%$ \\
\hline Total & 100 & $100 \%$ \\
\hline
\end{tabular}

nber: Data primer yang diolah, 2015

Dari tabel 4.4 diatas menunjukan

bahwa frekuensi kunjungan mayoritas antara lebih 2 kaliyaitu sebesar 74\% (74 orang) dan 2 kali sebesar $26 \%$ atau 26 orang. Hal ini menunjukkan bahwa loyalitas pengunjung/wisawatan obyek wisata pantai Baron termasuk dalam kriteria yang tinggi, sehingga kecenderungan ingin melakukan kunjungan kembali di obyek wisatan ini dalam waktu kedepan.

\section{Hasil Penelitian}

1. Hasil Uji Validitas

Uji validitas perlu dilakukan untuk mengetahui sejauh mana suatu alat ukur yang digunakan dalam penelitian dapat mengukur apa yang sebenarnya ingin peneliti ukur atau dapat digunakan untuk menguji instrumen penelitian agar instrumen tersebut dapat hasil sesuai dengan tujuan. Jika nilai $r$ hitung yang diperoleh lebih besar dari nilai $r$ tabel, nilai-nilai kritis yaitu pada taraf signifikan 5\% instrumen dicobakan dinyatakan valid. Sebaliknya jika $r$ hitung lebih kecil atau tidak sama dari $r$ tabel maka item tidak dapat dipakai atau tidak valid.

Tabel 4.10

Hasil Uji Validitas Pelayanan (PL)

\begin{tabular}{|c|c|c|c|}
\hline $\begin{array}{c}\text { Pertanyaan } \\
\text { (PL) }\end{array}$ & $\begin{array}{c}\text { R hitung } \\
\text { (component 5) }\end{array}$ & T tabel & Keterangan \\
\hline PL1 & .786 & 0.361 & Valid \\
\hline PL2 & .857 & 0.361 & Valid \\
\hline PL3 & .766 & 0.361 & Valid \\
\hline PL4 & .907 & 0.361 & Valid \\
\hline PL5 & .680 & 0.361 & Valid \\
\hline
\end{tabular}

Dari tabel diatas dapat diketahui bahwa variabel Pelayanan mempunyai lima item pertanyaan yang memiliki loading factor nilainya diatas 0,5 $(\square>0,5)$ dan mengumpul dalam konstruknya masing-masing(component 5). Dengan demikian seluruh item pertanyaan dapat dinyatakan valid.

Tabel 4.11

Hasil Uji Validitas Sarana Prasarana (SP)

\begin{tabular}{|c|c|c|c|}
\hline $\begin{array}{c}\text { Pertanyaan } \\
\text { (SP) }\end{array}$ & $\begin{array}{c}\text { R hitung } \\
\text { (component 3) }\end{array}$ & T tabel & Keterangan \\
\hline SP 1 & .802 & 0.361 & Valid \\
\hline SP 2 & .910 & 0.361 & Valid \\
\hline SP 3 & .904 & 0.361 & Valid \\
\hline SP 4 & .704 & 0.361 & Valid \\
\hline SP 5 & .939 & 0.361 & Valid \\
\hline
\end{tabular}

Dari tabel diatas dapat diketahui bahwa variabel Sarana Prasarana mempunyai lima item pertanyaan yang memiliki loading factor nilainya diatas 0,5 $(\square>0,5)$ dan mengumpul dalam konstruknya masing-masing 
(component 3). Dengan demikian seluruh item pertanyaan dapat dinyatakan valid.

Tabel 4.12

Hasil Uji Validitas Keunikan Objek (KO)

\begin{tabular}{|c|c|c|c|}
\hline $\begin{array}{c}\text { Pertanyaan } \\
(\mathrm{KO})\end{array}$ & $\begin{array}{c}\text { R hitung } \\
\text { (component 2) }\end{array}$ & T tabel & Keterangan \\
\hline KO 1 & .797 & 0.361 & Valid \\
\hline KO 2 & .919 & 0.361 & Valid \\
\hline KO 3 & .863 & 0.361 & Valid \\
\hline KO 4 & .828 & 0.361 & Valid \\
\hline KO 5 & .899 & 0.361 & Valid \\
\hline
\end{tabular}

Dari tabel diatas dapat diketahui bahwa variabel Keunikan Objek mempunyai lima item pertanyaan yang memiliki loading factor nilainya diatas $0,5 \quad(\square>0,5)$ dan mengumpul dalam konstruknya masing-masing (componen 2). Dengan demikian seluruh item pertanyaan dapat dinyatakan valid.

Tabel 4.13

Hasil Uji Validitas Keamanan (KA)

\begin{tabular}{|c|r|c|c|}
\hline $\begin{array}{c}\text { Pertanyaan } \\
\text { (KA) }\end{array}$ & $\begin{array}{c}\text { R hitung } \\
\text { (Component 4) }\end{array}$ & T tabel & Keterangan \\
\hline KA 1 & .887 & 0.361 & Valid \\
\hline KA 2 & .846 & 0.361 & Valid \\
\hline KA 3 & .894 & 0.361 & Valid \\
\hline KA 4 & .743 & 0.361 & Valid \\
\hline KA 5 & .826 & 0.361 & Valid \\
\hline
\end{tabular}

Sumber : Data Primer Diolah,2015

Dari tabel diatas dapat diketahui bahwa variabel Keamanan mempunyai lima item pertanyaan yang memiliki loading factor nilainya diatas 0,5 $(\square>0,5)$ mengumpul dalam konstruknya masing-masing (component 4). Dengan demikian seluruh item pertanyaan dapat dinyatakan valid.

Tabel 4.14

Hasil Uji Validitas Ketertarikan Wisatawan (KW)

\begin{tabular}{|c|c|c|c|}
\hline $\begin{array}{c}\text { Pertanyaan } \\
(\mathrm{KW})\end{array}$ & $\begin{array}{c}\text { R hitung } \\
\text { (Component 4) }\end{array}$ & T tabel & Keterangan \\
\hline KW 1 & .886 & 0.361 & Valid \\
\hline KW 2 & .917 & 0.361 & Valid \\
\hline KW 3 & .958 & 0.361 & Valid \\
\hline KW 4 & .913 & 0.361 & Valid \\
\hline KW 5 & .949 & 0.361 & Valid \\
\hline
\end{tabular}

Dari tabel diatas dapat diketahui bahwa variabel Keamanan mempunyai lima item pertanyaan yang memiliki loading factor nilainya diatas $0,5 \quad(0>0,5)$. mengumpul dalam konstruknya masingmasing (component 1). Dengan demikian seluruh item pertanyaan dapat dinyatakan valid.

\section{Hasil Uji Reliabilitas}

Uji reliabilitas untuk menguji ketepatan instrumen pengukur dengan konsistensi diantara bitir-butir pernyataan dalam suatu instrumen. Peneliti menguji instrumen peneliti dengan sampel sejumlah 30 responden. Untuk mengukur reliabilitas dalam penelitian ini adalah dengan membandingkan Cronbach Coefficient Alpha (r Alpha) pada hasil olahan SPSS Release 13.0 dengan Rule of Thumb / kesepakatan umum dari koefisien alfa yaitu lebih besar dari 0,6 untuk penelitian eksploratori.

Tabel 4.15

Hasil Uji Reliabilitas

\begin{tabular}{|l|c|c|c|}
\hline \multicolumn{1}{|c|}{ Variabel } & $\begin{array}{c}\text { Koef. Alpha } \\
\text { Cronbach's }\end{array}$ & $\begin{array}{c}\text { Nilai } \\
\text { Kritis }\end{array}$ & Keterangan \\
\hline X1 : PELAYANAN & 0.888 & 0.6 & Reliabel \\
\hline X2 : SARANA PRASARANA & 0.912 & 0.6 & Reliabel \\
\hline X3 : KEUNIKAN OBJEK & 0.925 & 0.6 & Reliabel \\
\hline X4: KEAMANAN & 0.915 & 0.6 & Reliabel \\
\hline $\begin{array}{l}\text { Y:KETERTARIKAN } \\
\text { WISATAWAN }\end{array}$ & 0.965 & 0.6 & Reliabel \\
\hline \multicolumn{2}{|r|}{ Sumber : Data Primer Diolah,2015 }
\end{tabular}

Hasil

uji reliabilitas menunjukkan bahwa seluruh variabel penelitian memiliki koefisien Alpha Cronbach's $>0,6$. Dengan demikian semua item pertanyaan dalam mengukur variabel penelitian dapat dinyatakan reliabel.

3. Hasil Uji Regresi Linier Berganda

Estimasi Regresi Linear Berganda

\begin{tabular}{|l|c|c|c|c|c|}
\hline \multicolumn{1}{|c|}{ Variabel } & $\begin{array}{c}\text { Regrecion } \\
\text { Coeficient }\end{array}$ & Beta & T hitung & Sig t & Keterangan \\
\hline Constanta (Bo) & 0.792 & & 2.700 & 0.008 & Positif \\
\hline Pelayanan & 0.163 & 0.210 & 2.456 & 0.016 & Positif \\
\hline Sarana prasarana & 0.187 & 0.211 & 2.604 & 0.011 & Positif \\
\hline Keunikan Objek & 0.261 & 0.305 & 3.468 & 0.001 & Positif \\
\hline Keamanan & 0.211 & 0.244 & 2.822 & 0.006 & Positif \\
\hline
\end{tabular}

Interpretasi Persamaan Regresi Dalam persamaan regresi di atas, konstanta (Y) adalah sebesar 0,792. Maka berarti jika variabel Pelayanan, Sarana prasarana, Keunikan objek, dan 
Keamanan bernilai nol, maka Ketertarikan wisatawan pada obyek wisata pantai Baronakan sebesar 0,792 satuan.

Variabel Pelayanan (X1)

Merupakan variabel yang mempengaruhi Ketertarikan wisatawan dengan koefisien positif sebesar 0,163. Hal ini dapat diartikan bahwa pengaruh Pelayanan pada obyek wisata pantai Baron terhadap ketertarikan wisatawan positif, artinya semakin baik Pelayanan maka ketertarikan wisatawan tersebut juga akan semakin meningkat.

Variabel Sarana prasarana (X2)

Merupakan variabel yang mempengaruhi Ketertarikan wisatawan dengan koefisien regresi yang positif sebesar 0,187. Hal ini dapat diartikan bahwa pengaruh sarana prasarana terhadap ketertarikan wisatawan positif, artinya sarana prasarana semakin baik maka ketertarikan wisatawan tersebut juga akan semakin meningkat.

Variabel Keunikan objek (X3)

Merupakan variabel yang mempengaruhi Ketertarikan wisatawan dengan koefisien regresi yang positif sebesar 0,261 . Hal ini dapat diartikan bahwa pengaruh Keunikan objek terhadap ketertarikan wisatawan positif, artinya semakin baik maka ketertarikan wisatawan tersebut juga akan semakin meningkat.

Variabel Keamanan (X4)

Merupakan variabel yang mempengaruhi Ketertarikan wisatawan dengan koefisien regresi yang positif sebesar 0,211. Hal ini dapat diartikan bahwa pengaruh Keamanan terhadap ketertarikan wisatawan positif, artinya semakin meningkat keamanan yang kenyamanan yang dirasakan pengunjung maka ketertarikan wisatawan tersebut juga akan semakin meningkat.

\section{Hasil Uji Parsial (Uji T)}

Tabel 4.17

Hasil Uji T (Uji Parsial)

\begin{tabular}{|l|c|c|c|}
\hline \multicolumn{1}{|c|}{ Variabel } & T hitung & Sig t & Keterangan \\
\hline Constanta (Bo) & 2.700 & 0.008 & Signifikan \\
\hline Pelayanan & 2.456 & 0.016 & Signifikan \\
\hline Sarana prasarana & 2.604 & 0.011 & Signifikan \\
\hline Keunikan Objek & 3.468 & 0.001 & Signifikan \\
\hline Keamanan & 2.822 & 0.006 & Signifikan \\
\hline
\end{tabular}

Sumber : Data Primer diolah, 2015

a. Pengujian terhadap koefisien regresi pada variabel Pelayanan (X1)

Hasil pengujian signifikansi menunjukkan bahwa variabel Pelayanan (X1) terdapat nilai probabilitas sebesar 0,016, yang berarti Sig <0,05. Nilai tersebut dapat membuktikan Ho ditolak yang berarti bahwa ada pengaruh variabel Pelayanan secara signifikan terhadap Ketertarikan wisatawan pada obyek wisata pantai Baron.Dengan demikian hipotesis pertama dalam penelitian ini yang menyatakan "Pelayanan berpengaruh positif dan signifikan terhadap ketertarikan wisatawan" didukung.

b. Pengujian terhadap koefisien regresi Sarana prasarana (X2)

Hasil pengujian signifikansi menunjukkan bahwa variabel Sarana prasarana (X2) terdapat nilai probabilitas sebesar 0,011, yang berarti $\operatorname{Sig}<0,05$. Nilai tersebut dapat membuktikan Ho ditolak yang berarti bahwa ada pengaruh variabel Sarana prasarana secara signifikan terhadap Ketertarikan wisatawan pada obyek wisata pantai Baron. Dengan demikian hipotesis kedua dalam penelitian ini yang menyatakan "Sarana prasarana berpengaruh positif dan signifikan terhadap ketertarikan wisatawan" didukung 
c. Pengujian terhadap koefisien regresi pada variabel Keunikan objek (X3)

Hasil pengujian signifikansi menunjukkan bahwa variabel Keunikan objek (X3) terdapat nilai terdapat nilai probabilitas sebesar 0,001 , yang berarti $\mathrm{Sig}<0,05$. Nilai tersebut dapat membuktikan Ho ditolak yang berarti bahwa ada pengaruh variabel Keunikan objek secara signifikan terhadap Ketertarikan wisatawan pada obyek wisata pantai Baron. Dengan demikian hipotesis ketiga dalam penelitian ini yang menyatakan "keunikan objek berpengaruh positif dan signifikan terhadap ketertarikan wisatawan" didukung.

d. Pengujian terhadap koefisien regresi Keamanan (X4)

\begin{tabular}{llrr}
\multicolumn{1}{c}{ Hasil pengujian } & signifikansi \\
menunjukkan & bahwa & variabel \\
Keamanan & (X4) terdapat & nilai \\
probabilitas & sebesar & 0,006, & yang
\end{tabular} berarti Sig <0,05. Nilai tersebut dapat membuktikan Ho ditolak yang berarti bahwa ada pengaruh variabel Keamanan secara signifikan terhadap Ketertarikan wisatawan pada obyek wisata pantai Baron. Dengan demikian hipotesis keempat dalam penelitian ini yang menyatakan "Keamanan berpengaruh positif dan signifikan terhadap ketertarikan wisatawan" didukung

5. Hasil Uji Simultan (Uji F)

\begin{tabular}{|l|r|r|r|r|r|}
\hline \multicolumn{1}{|c|}{ Model } & $\begin{array}{c}\text { Sum of } \\
\text { Squares }\end{array}$ & \multicolumn{1}{c|}{ Df } & Mean Square & F & \\
\hline Regression & 14.290 & 4 & 3.572 & 30.887 & $.000^{\mathrm{a}}$ \\
\hline Residual & 10.992 & 95 & .116 & & \\
\hline Total & 25.282 & 99 & & & \\
\hline
\end{tabular}

Hasil uji F diperoleh F hitung sebesar 30,877 dan probabilitas sebesar 0,000 . Karena Sig $\mathrm{F}<0,05$, maka Ho ditolak dan Ha diterima, atau dapat disimpulkan bahwa ada pengaruh secara serentak variabel independen yang terdiri dari variabel Pelayanan, Sarana prasarana, Keunikan objek, dan Keamanan terhadap Ketertarikan wisatawan pada obyek wisata pantai Baron.

6. Hasil Uji Koefisien Determinasi

\begin{tabular}{l|r|r|r|r}
\multicolumn{7}{c}{ Tabel 4.19 } \\
\hline Model & \multicolumn{1}{c}{ H } & R Square & Adjusted R Square & $\begin{array}{l}\text { Std. Error of } \\
\text { the Estimate }\end{array}$ \\
\hline 1 & .752 & .565 & .547 & .34015 \\
\hline Sumber : Data Primer diolah, 2015 & .547 &
\end{tabular}

Hasil koefisien korelasi berganda seperti pada tabel 4.18 adalah sebesar 0,752.Nilai ini cenderung mendekati angka 1 sehingga dapat diartikan bahwa terdapat hubungan yang kuat antara variabel independen (Pelayanan, Sarana prasarana, Keunikan objek, dan Keamanan) dengan Ketertarikan wisatawan pada obyek wisata pantai Baron. Artinya bahwa secara rata-rata setiap terjadi peningkatan pada Pelayanan, Sarana prasarana, Keunikan objek, dan Keamanan maka ketertarikan wisatawan akan semakin meningkat.

\section{Pembahasan}

Hasil penelitian menemukan bahwa Pelayanan berpengaruh positif dan signifikan terhadap ketertarikan wisatawan pada obyek wisata pantai Baron. Hal ini berarti semakin besar tingkat Pelayanan yang diberikan pengelola obyek wisata kepada pengunjung maka ketertarikan wisatawan akan semakin kuat. Pelayanan kepariwisataan merupakan suatu tindakan yang dilakukan guna memenuhi keinginan custimer (pengunjung) akan sesuatu produk atau jasa yang mereka butuhkan, tindakan ini dilakukan untuk memberikan kepuasan kepada pengunjung untuk memenuhi apa yang mereka butuhkan tersebut.Dalam kontek destinasi pariwisata, tingkat kepuasan turis akan tercapai, jika layanan yang 
diharapkan adalah sama dengan pelayanan yang dirasakan. Pelanggan akan lebih puas jika kesenjangan antara layanan yang diharapkan dan pelayanan yang dirasakan tersebut kecil. Singkatnya, karena jasa merupakan bagian penting dari pengalaman pariwisata, kualitas pelayanan merupakan aspek penting untuk memuaskan para wisatawan, dan hal ini merupakan dasar terhadap ketertarikan wisatawan untuk berkunjung kembali di Pantai Baron.

Hasil penelitian menemukan bahwa sarana prasarana berpengaruh positif dan signifikan terhadap ketertarikan wisatawan pada objek wisata

Pantai Baron. Hal ini berarti semakin baik sarana dan prasarana yang disediakan pemerintah darah Kabupaten Gunungkidul maka ketertarikan wisatawan akan semakin kuat. Menurut (Bagyono, 2005), sarana pariwisata adalah fasilitas dan perusahaan yang memberikan pelayanan kepada wisatawan baik secara langsung maupun tidak langsung. Maju mundurnya sarana kepariwisataan tergantung pada jumlah kunjungan wisatawan. Oleh karena itu keberadaan sarana pariwisata sangatlah penting dan mutlak untuk menyajikan pelayanan yang berkualitas kepada para wisatawan.Sedangkan prasarana pariwisata adalah fasiltas utama atas dasar yang memnungkinkan sarana kepariwisataan dapat hidup dan berkembang dalam rangka memberikan pelayanan pada wisatawan.

Hasil penelitian menemukan bahwa keunikan obyek pantai Baron berpengaruh positif dan signifikan terhadap ketertarikan wisatawan pada objek wisata Pantai Baron. Hal ini berarti semakin baik keunikan obyek wisata pantai Baron maka ketertarikan wisatawan akan semakin kuat. Obyek wisata yang unik berarti obyek wisata ini memiliki keunggulan yang tidak dijumpai pada obyek wisata lainnya. Salah satu keunikan Pantai Baron adalah terdapat muara sungai bawah tanah yang dapat digunakan untuk pemandian setelah bermain di laut. Pertemuan air laut dan air tawar ini memang menjadi daya tarik sendiri bagi pengunjung. Konon, dengan mengunjungi lokasi pertemuan air tawar dan air laut di Pantai Baron ini, maka dua insan dari status atau golongan yang berbeda dapat bersatu. Terlepas dari benar atau tidaknya mitos tersebut, Pantai Baron Gunungkidul yang terletak sekitar 60 kilometer dari pusat kota Yogyakarta ini memang menyimpan daya tarik luar biasa yang membuat pengunjung betah menghabiskan waktu liburan disana Hasil penelitian menemukan bahwa keamanan berpengaruh positif dan signifikan terhadap ketertarikan wisatawan pada objek wisata Pantai Baron. Hal ini berarti semakin baik keamanan wisatawan pada obyek wisata pantai Baron maka ketertarikan wisatawan akan semakin kuat. Keamanan mutlak dibutuhkan oleh wisatawan, karena obyek wisata yang aman akan meningkatkan kenyamanannya. Faktor kenyamanan dan keamanan pada suatu kawasan pariwisata merupakan nilai tambah dan perluang untuk dikunjungi oleh wisatawan. Sebagaimana yang dimaksudkan (UNWTO, 2004) bahwa destinasi wisata di negara berkembangsudah saatnya untuk memberikan alternatif berwisata dengan jaminan keselamatan dan rasa aman bagi wisatawan selama berwisata. Pantai Baron merupakan pantai yang sudah lama menjadi andalan Pemerintah Kabupaten Gunungkidul, sehingga dari segi keamanan sudah sesuai dengan standar keselamatan. Hal ini didukung dengan akses jalan menuju lokasi wisata ini terbilang aman, tim SAR yang berada di Pantai Baron sigap dan bekerja dengan baik dan didukung dengan tempat parkir yang luas serta dukungan masyarakat. 


\section{KESIMPULAN DAN SARAN}

\section{Kesimpulan}

1. Pelayanan berpengaruh positif dan signifikan terhadap ketertarikan wisatawan. Hal ini berarti semakin besar Pelayanan maka semakin tinggi pula ketertarikan wisatan pada obyek wisata pantai Baron.

2. Sarana prasarana berpengaruh positif dan signifikan terhadap ketertarikan wisatawan. Hal ini berarti semakin besar sarana prasarana maka semakin tinggi pula ketertarikan wisatan pada obyek wisata pantai Baron.

3. Keunikan objekberpengaruh positif dan signifikan terhadap ketertarikan wisatawan. Hal ini berarti semakin besar keunikan obyek wisata maka semakin tinggi pula ketertarikan wisatan pada obyek wisata pantai Baron.

4. Keamanan berpengaruh positif dan signifikan terhadap ketertarikan wisatawan. Hal ini berarti semakin besar keamanan maka semakin tinggi pula ketertarikan wisatan pada obyek wisata pantai Baron.

5. Secara serentak variabel Pelayanan, sarana prasarana, keunikan objek dan keamanan berpengaruh signifikan terhadap ketertarikan wisatawan pada obyek wisata pantai Baron. Sedangkan besarnya pengaruh keempat variabel independen terhadap variabel dependen adalah sebesar $54,7 \%$, dan sisanya sebesar $45,3 \%$ ketertarikan wisatawan dipengaruhi oleh variabel lainnya.

\section{Saran}

1. Untuk menarik minat Investor untuk menanamkan modalnya di sektor pariwisata Kabupaten Gunungkidul sebaiknya terus melakukan promosi kepariwisataan lewat berbagai media. Dengan mengetahui peluang apa saja yang dapat dikembangkan untuk suatu investasi di objek wisata, peneliti berharap objek pariwisata di Kabupaten Gunungkidul akan terus berkembang.

2. Bagi Masyarakat diharapkan dapat memanfaatkan sumber daya alam yang ada khususnya tempat-tempat pariwisata disekitar mereka untuk dijadi sebuah peluang usaha. Namun tetap, masyarakat harus memperhatikan aspek-aspek kelestarian sumber daya yang ada tersebut.

3. Bagi pemerintah Kabupaten Gunungkidul khususnya Dinas Pariwisata, hendaknya memperhatikan pelayanan kepada wisatawan, mengingat variabel ini berpengaruh terhadap ketertarikan wisatawan, terutama dalam hal kebersihan pantai misalnya dengan menyediakan petugas kebersihan yang bekerja secara teratur membersihkan area wisatawan. Selain itu dalam hal sarana dan prasaran perlu adanya penerangan pada jalur menuju pantai. Dalam hal keunikan objek perlu mempertahankan keunikan pada pertukaran air tawar dan air laut yang menjadi ciri khas Baron, sehingga dengan warga masyarakat terus memelihara sungai dan lingkungan pantai. Sementara dalam hal keamanan, perlu adanya tindakan yang tegas dari penjaga pantai untuk melarang keras wisatawan yang mandi di laut terutama di saat sedang ombak besar, untuk menghindari kecelakaan atau musibah lainnya.

4. Bagi peneliti selanjutnya hendaknya melakukan penelitian yang sama dengan menggunkaan obyek wisata lainnya, dengan sampel yang lebih besar dan menambahkan variabel lain yang diduga mempengaruhi ketertarikan wisatawan terhadap destinasi obyek wisata. 


\section{DAFTAR PUSTAKA}

Bagyono. 2005. Pariwisata dan Perhotelan. Bandung : Alfabeta.

Buchari, Alam. 2007. Manajemen Pemasaran dan Pemasaran Jasa. Bandung : CV. Alfabeta.

$\begin{array}{lcr} & .2008 . & \text { Manajemen } \\ \text { Pemasaran } & \text { dan } & \text { Pemasaran } \\ \text { Jasa.Bandung : Alfabeta. } & \end{array}$

Bungin, Alma. 2009. Penelitian Kuantitatif. Jakarta : Kencana. 2006. Sosiologi Komunikasi. Jakarta : Kencana.

Bursan, Rinaldi. 2006. Jurnal Kepuasan Pariwisata,Analisis Pengaruh Dimensi Wisata terhadap Loyalitas.

Fandeli, Chafid. 1995. Dasar-dasar Manajemen Kepariwisataan Alam. Liberty : Yogyakarta.

Ghozali, Imam. 2005. Aplikasi Analisis Multivariate dengan ProgramSPSS. Semarang: Badan Penerbit Universitas Diponegoro.

Hair et al. 1998. Multivariante Data Analysis, Fifth Edition, Prentice Hall, Upper. New Jersy :Saddle River.

Hasan, Ali. 2008. Marketing. Yogyakarta : Media Utama.

Inskeep, Edward. 1991. Tourism Planning:An Integrated and Sustainable.Development Approach. New York. US

Kotler. 2002. Marketing Managemen. The Mulenium Edition, 10 th Edition. New Jersey : Prentice Hall.

Kotler dan Amstrong. 2004. Prinsipprinsip Marketing. Edisi Ketujuh. Yogyakarta : Penerbit Andi.

Kotler, Philip. 2009. Marketing Management. Prentice Hall, United State Of America.

Kotler, Philip dan Keller K Lane. 2006. Manajemen Pemasaan. Jakarta :Ghalia. Indonesia.

Kövàri, I Dan Zimànyi. 2011. Safety and Security in the Age of GlobalTourism (The chaning role and conception of Safety and Security In Tourism). Budapest : Agroinfrom Publishing House.

Morrisan. 2007. Periklanan : Komunikasi Pemasaran Jasa.Bandung :Alfabeta.

Siagian dan Sugiarto. 2006. Metode Statistika. Jakarta: Gramedia Pustaka Utama.

Sugiyono. 2004.Metode Penelitian Bisnis. Bandung: CV. Alfabeta . 2008. Metode Penelitian Bisnis. Bandung: CV. Alfabeta

2010. Metode Penelitian Kuantitatif Kualitatif dan RND. Bandung: Alfabeta.

Suwantoro, Gamal. 2002. Dasar-dasar Pariwisata. Yogyakarta : Penerbit Andi.

2004. Dasar-dasar Pariwisata. Yogyakarta: Andi.

Swasta, Basu. 2003. Azas-azas Marketing. Yogyakarta : Liberty. 